\title{
Does Corporate Investment Efficiency Affect Corporate Disclosure Practices?
}

\author{
Dr. Noha Elberry*, \\ Arab Academy for Science, Technology and Maritime Transport \\ Alexandria, Egypt \\ Email: nohaelberry@aast.edu \\ Telephone: +201004993536
}
Professor Khaled Hussainey
University of Portsmouth
United Kingdom

Email: Khaled.Hussainey@port.ac.uk

* Corresponding author 


\title{
Does corporate investment efficiency affect corporate disclosure practices?
}

\begin{abstract}
Purpose: We examine the impact of corporate investment efficiency on corporate voluntary disclosure for a sample of UK non-financial companies.

Design: We use a sample of FTSE All Share firms for the period 2007-2014. Disclosure scores are collected from Corporate Financial Information Environment (CFIE). We follow Biddle et al. (2009) and Chen et al. (2011) in measuring corporate investment efficiency.

Findings: We find that high level of performance-related disclosure is associated with high level of corporate investment efficiency, while high level of good news information is associated with low level of corporate investment efficiency. We also find evidence on a bidirectional relation between disclosure and corporate investment efficiency.

Research implications: Our findings would be of importance to stakeholders and corporations. Stakeholders' investment decisions could be facilitated by understanding the disclosures provided by their firms and how these firms' performance is presented. Corporations become aware of the language, which must be used to signal their performance.

Originality: Our paper adds to disclosure studies by introducing a new variable, corporate investment efficiency, as a determinant of corporate disclosure practice.

Keywords: Corporate investment efficiency, voluntary disclosure, disclosure tone, United Kingdom
\end{abstract}

\section{Introduction}

We examine the impact of corporate investment efficiency on the voluntary disclosure practices for UK firms. The UK is an interesting context because majority of narrative sections of corporate annual reports are voluntary in nature. We add to accounting literature on the determinants of voluntary disclosure by introducing new variable, corporate investment efficiency, as a potential driver for disclosure. We are interested to see if high level of corporate investment efficiency motivates UK firms to voluntarily disclose more performance-related information or less good/bad news information in their annual report narratives. While prior research provides evidence that information asymmetry (e.g. level of disclosure) affects corporate investment efficiency (Lai et al., 2014) - Although this may be the case - we argue that corporate investment efficiency might be an indicator of a good internal control system, good governance system, and an indicator for quality management. We, argue, believe higher levels of investment efficiency might be associated with less information asymmetry and more disclosure in the annual report narratives. We revisit 
the efficiency- disclosure literature and test to see if the is any relationship between the variables in a sample of UK firms. We also examine if there is a bidirectional relationship between corporate investment efficiency and disclosure practice.

We use Biddle et al. (2009) and Chen et al. (2011) measurements of investment efficiency. The disclosure scores were downloaded from the CFIE site, measuring voluntary disclosure by the total number of words "Wordcountsum" and the net positive keywords divided by positive plus negative keywords "net_tone_performance" of the performance commentaries (El-Haj et al., 2019).

We find that investment efficiency affects voluntary disclosure of performance indicators positively which is consistent with signalling theory. As when firms invest efficiently, an increased level of transparency would give a positive signal to stakeholders, and thereof improves the firms' image and reputation. On the other hand, we find that disclosure tone is negatively affected by investment efficiency levels. Proprietary costs theory explains this association; firms' competitive advantage is protected by not disclosing good news information regarding the boost in investment efficiency. This finding also might suggest that firms with inefficient investment decision may disclose more good news information to convince their stakeholders that such low level of investment efficient is not an indicator for the long-term success of the firm. They might disclose more good news information to explain why such inefficiencyarises and when the firm will improve its efficiency. Finally, we find a bidirectional relationship between corporate investment efficiency and disclosure practice.

The rest of the paper is organised as follows: Section 2 reviews the literature; section 3 discusses the method. Section 4 discusses the empirical findings. Section 5 concludes.

\section{Literature review}

On one hand, the impact of voluntary disclosure on corporate investment efficiency has been investigated in the literature. Cheng et al. (2013) find that internal control weakness disclosures 
improve investment efficiency through better monitoring and increased financial reporting quality. In addition, Lai et al. (2014) and Al-Hadi et al. (2016) conclude that increasing market risk disclosures or disclosures in general in terms of quantity and quality boost a firm's investment efficiency. The literature also shows that raising the reporting level of corporate social responsibility, future cash flows and capital stock would reduce investment inefficiencies (Dutta and Nezlobin, 2017; Zhong and Gao, 2017). Guttman and Meng (2018) find that managers may over invest in information acquisition and choose risky projects where there is higher cost of ignorance at the investment stage due to the voluntary nature of disclosure leading to these inefficiencies. So, literature concludes that corporate disclosure leads to an improvement in corporate investment efficiency.

On the other hand, considering investment efficiency as a determinant of corporate disclosure is justified as follows. According to Bamber et al. (2010), top executives exert unique and economically significant influence (manager-specific fixed effects) on their firms' voluntary disclosures. For example, managers with finance and accounting background favour more accurate disclosure styles. Baik et al. (2011) state that consistent with Trueman's (1986) theory, the likelihood and frequency of management earnings forecasts increase with CEO ability. Baik et al. (2017) conclude that as managers have higher equity incentives (ability), firms' information environment (broader than the specific financial reporting disclosures) improves. Gul et al. (2018) find that higher managerial ability increases audit fees, a proxy for financial reporting quality, for financially distressed firms and vice versa for non-distressed ones. In addition, Abernathy et al. (2018) find that managerial ability has a positive influence on the timeliness of financial reporting. These studies suggest that there is a link between managerial ability and voluntary disclosure. The main measurement of managerial ability is the MA-score developed by Demerjian et al. (2012).The score generates an estimate of how efficiently managers use their firms' resources. Firms use inputs like Cost of Goods Sold (COGS), selling and administrative expenses, net 
Property, Plant and Equipment (PP\&E), net Research and Development (R\&D) and purchased goodwill to generate outputs such as revenues or income (Demerjian et al., 2013). Higher ability managers must generate higher revenues from their available set of resources than other members in the same industry (Habib and Hasan, 2018; Lee et al., 2018). Therefore, it is expected that corporate investment efficiency can be a precise proxy for managerial ability. Therefore, our study examines the impact of increased management ability in terms of higher investment efficiency on firms’ voluntary disclosure.

Chen et al. (2017) investigate the bidirectional relationship between investment efficiency and investment transparency. They find no impact of investment transparency on investment efficiency, this contradicts the results of Biddle et al. (2009) and Gomariz and Ballesta (2014) who suggest that financial reporting quality (FRQ) mitigates investment inefficiencies through reducing information asymmetry. The lack of association could be due to the unconfirmed managers' forecasts regarding projects' profitability. Thus, the reduction of information asymmetry, in this case, turns to be less effective.

Chen et al. (2017) argue that a negative association between investment efficiency and disclosure indicates that managers with inefficient investment decision may disclose more information to justify their deviations from optimal investments.

We examine the effect of corporate investment efficiency on voluntary disclosure. Voluntary disclosure is considered broader term than investment transparency. As voluntary disclosure refers to the willingness of disclosing any type of information related to the firm. While investment transparency considers only certain projects' capital expenditure announcements when determining the disclosure quality, which is the measurement of investment transparency as indicated by Chen et al. (2017). To solve the limitation of having investment transparency as a narrower scope, voluntary disclosure was considered. As when firms invest efficiently or inefficiently this does not only impact the transparency about investments but also various 
operating and financial aspects. Therefore, investigating performance commentary in annual report narratives indicates how firms' disclosure on performance-related information such as profits, expenditures, productivity and cash flows are affected by their levels of investment efficiency. In addition, the sample investigated includes UK listed firms unlike that of Chen et al. (2017) which investigate Australian firms, and so results might be different as the economic conditions are. Accordingly, either a positive or a negative impact of corporate investment efficiency on voluntary disclosure can be found. In case of a positive impact, firms investing efficiently tend to disclose more to attract potential investors, satisfy current shareholders, calm down lenders and creditors, and reduce information asymmetries and costs of equity financing. While if there is a negative effect, this result will be similar to that of Chen et al. (2017). When firms over or under-invest, firms are more encouraged to use impression management (Godfrey et al., 2003; Aerts, 2005). Managers would be eager to disclose more by giving a self-serving view to stakeholders to control and modify their impressions about firms' performance (Courtis, 2004; Merkl-Davies et al., 2011; Leung et al., 2015). We expect that corporate investment efficiency could impact both performance-related and good news information in annual report narratives. We, therefore, formulate the following hypotheses:

H1: Corporate investment efficiency has an impact on levels of voluntary disclosure.

H2: Corporate investment efficiency has an impact on net disclosure tone levels.

\section{Research methodology}

\subsection{Data collection and sample selection}

We collect data for non-financial FTSE all share index from 2007 until 2014. We exclude financial companies due to the highly regulated disclosure environment they have to comply with (Athanasakou and Hussainey, 2014). The sample period was chosen to cover the economic crisis year (2008) and the years after in order to analyse its long-term consequences. Lancaster's (CFIE) 
list of UK annual reports narrative disclosures scores only provide data until 2014, therefore the sample's period ends that year.

The UK context was selected for a number of reasons. First, narrative reporting in the UK is mainly voluntary, thus regulatory and litigation costs are low compared to other countries such as US and Canada (La Porta et al., 2006; Aerts and Tarca, 2010). Second, there are considerable parts of UK's annual report narratives that are not verifiable or auditable (Athanasakou and Hussainey, 2014), so it is interesting to examine motivations of such disclosure. Third, UK annual reports have a significant level of impression management regarding firms' performance (Clatworthy and Jones, 2006). Therefore, we focus on the UK to test factors affecting the voluntary sections of annual reports' narrative reporting.

The FTSE all-share index was filtered to only include in the sample companies, which continue to be listed between 2007 until 2014 accounting for 256 firm-year observations.

Corporate investment efficiency and control variables' data were collected from the Bloomberg database. Then, investment efficiency and control variables' data were matched with the existing disclosure scores (from CFIE).

The number of companies that have available investment efficiency, control variables and voluntary performance commentary disclosure scores (first proxy) are 151 with a total of 441observations. While for the disclosure tone (second proxy), the number of companies with available investment efficiency, control variables and disclosure tone scores are 151 with 428 observations.

The selected sample includes 9 different industrial sectors categorized according to Bloomberg database over the period 2007-2014, as shown in table (1). The industrial sector represents the highest number of companies among other sectors of $33.77 \%$, while the lowest numbers of companies are from the telecommunications sector forming only $2.66 \%$ of the total companies. 


\section{Variables measurements}

\section{Dependent variable}

The two proxies for the dependent variable voluntary disclosure are expressed in this section, explaining why these proxies were selected and from which source.

\section{First proxy "Wordcountsum"}

To obtain the disclosure scores, the CFIE Wmatrix-import web tool which permits batch scoring of UK annual report narratives was used ${ }^{1}$. Wmatrix has the ability to process unstructured annual reports in an electronic format and produce word count frequencies based on predetermined dictionaries (Pappas, 2015; Lewis and Young, 2019; El-Haj et al., 2019; El-Haj et al., 2019). CFIE collects electronic versions of the UK reports for the years 2002-2014. The collection started from 2007 and ends in 2014, covering the period during and after the economic crisis; moreover, to maintain the consistency between the other samples' period of our study.

The considered sections of UK annual reports were the performancecommentaries, which discuss any aspect of operating activities, or financial performance that is why they were taken into consideration instead of the overall voluntary disclosure. The overall voluntary disclosure is more general, as it includes, for example, CSR reports, remuneration reports or governance statements, which might not reflect a firm's investment efficiency or inefficiency practices as the performance commentaries can do.

The total number of words of a section " $s$ " in an annual report was used as a proxy, known as wordcountsum. Therefore, disclosure scores attained as data gathered were the word count for the aggregate performance commentary identified as wordcountsum_Perform. The performancerelated keywords as searched for by Wmatrix software are as follows:

Performance keywords (\# stands for any number of characters):

\footnotetext{
${ }^{1}$ The CFIE Wmatrix web import tool is available at https://cfie.lancaster.ac.uk:8443/.
} 


\begin{tabular}{|l|l|}
\hline Sales & Revenue \\
\hline Revenues & Turnover \\
\hline Trading & Cost \\
\hline Costs & Expense \\
\hline Expenses & Income \\
\hline Earnings & e.p.s \\
\hline Profit & Profits \\
\hline Profitability & Loss \\
\hline Losses & Margin \\
\hline Margins & Result \\
\hline Results & \\
\hline
\end{tabular}

\section{Second proxy "Disclosure tone"}

Continuing with UK annual reports performance commentaries and for being more specific and narrowing the focus, disclosure tone was selected as a reflection of a company's performance. Given the same time interval and source of data, the net positive keywords divided by positive plus negative keywords for the performance commentary were selected known as net_tone_performance. Therefore, disclosure tone is a dependent variable reflecting the percentage of good news relative to the total of good and bad news combined together. This variable is crucial for companies that have changes in investment efficiencies by checking the impact of such changes on not only the level of voluntary disclosure but also the tone of their discussion in the form of being good or bad news about the companies. Examples of negativity keywords include disappoint, risk, threat, fail,...etc. and examples of positivity keywords include delighted, rewards, successes,...etc., all are searched for on the CFIE Wmatrix site ${ }^{2}$.

\section{Independent and control variables}

Our independent variable is corporate investment efficiency. We use the two most commonly used proxies (Biddle et al., 2009; Chen et al., 2011) to measure this variable. Second, we choose the

\footnotetext{
${ }^{2}$ The links to positivity and negativity keywords are available at http://ucrel.lancs.ac.uk/cfie/files/HenryNeg2006.txt and http://ucrel.lancs.ac.uk/cfie/files/HenryPos2008.txt
} 
control variables based on prior studies (Barako et al., 2006; Lan et al., 2013; Ressas and Hussainey, 2014; Habbash et al., 2016; Aly et al., 2018).

Investment efficiency's first proxy

Chen et al. (2011) measure investment efficiency as deviations from expected investment using a model that forecasts investment as a function of growth opportunities. This measurement is consistent with Biddle et al. (2009) for measuring investment efficiency. Principally, Hubbard (1998) estimates a prudent model for expected investment as a function of sales growth. Since the relation between investment and sales growth could differ between sales declines and sales boosts, a linear regression model is employed to consent a differential predictability for sales fluctuations:

$$
\text { Invest }_{i, t}=\alpha 0+\alpha_{1} N E G_{i, t-1}+\alpha_{2} \text { SalesGrowth }_{i, t-1}+\alpha_{3} N E G^{*} \text { SalesGrowth }_{i, t-1}+\varepsilon_{i, t}
$$

In equation 1, Invest $_{i, t}$ is the total investment of firm $i$ in year $t$, defined as the net increase in tangible and intangible assets and scaled by lagged total assets ${ }^{3}$. SalesGrowth h $_{i,-1}$ is the annual sales growth rate for firm $i$ in year $t-1$ and $N E G_{i, t-1}$ is an indicator variable which takes the value of one for negative sales growth and a zero otherwise (Gomariz and Ballesta, 2014).

Calculating investment efficiency or inefficiency occurs by multiplying the absolute value of the residuals by negative 1 since both over or underinvestment reflects an unfavorable sign about the efficiency level. Therefore, the residuals from the regression model reveal the deviation from the expected investment level indicating that those residuals are used as a firm-specific proxy for investment inefficiency. A positive residual means that the firm is making investments at a higher rate than estimated according to the sales growth, so it will overinvest. In contrast, a negative residual assumes that real investment is less than the estimated, reflecting an underinvestment.

${ }^{3}$ Chen et al. (2011) and Biddle et al. (2009) are two measurements differing in the part of forecasting investments as a function of growth opportunities. The investment is calculated by Chen et al. (2011) as the net increase in tangible and intangible assets and scaled by lagged total assets. So the available data for assets purchased or disposed is accounted for, unlike Biddle et al. (2009) measurement of investment which specifies certain items for measuring. 
Investment efficiency's second proxy

The most frequently used proxy for investment efficiency is the one proposed by Richardson (2006) and Biddle et al. (2009). A firm's total investment for a given year, indicated in equation 2 by Investment (I), is measured as the sum of $\mathrm{R} \& \mathrm{D}$, capital expenditures, and acquisition expenditures minus the cash receipts from the sales of PPE multiplied by 100 and scaled by average total assets:

$$
I_{t}=R D_{t}+C A P E X_{t}+\text { Acquisitions }_{t}-\text { SalePPE }_{t}(2)
$$

This measurement of investment is clearly distinguished from other ones since it takes into consideration various investment classes by including capital expenditures, acquisitions, sales of assets and R\&D. These investment types incorporate a significant importance nowadays, unlike old previous research, which studied and discussed these components individually.

The abnormal element of investment or the residuals reflected in the error term are then used as a proxy for investment inefficiency levels by determining whether there is an over or underinvestment. Biddle et al. (2009) state that investment inefficiency takes values between zero and one, where zero or values close to zero indicates underinvestment, while one or values close to one specifies overinvestment.

Voluntary disclosure control variables (first proxy "Wordcountsum”)

According to previous literature, firm size, leverage, profitability, liquidity, growth, and age are considered the main determinants of corporate voluntary disclosure. Firm size is measured by the natural logarithm of assets (Cooke, 1989a; Hassan et al., 2006; Al-Hadi et al., 2016; Mohamed and Schwienbacher, 2016). Leverage or gearing of a company is measured through the book value of debt to total assets ratio (Eng and Mak, 2003; Al-Hadi et al., 2016). For measuring profitability, a firm's ROA ratio is used (Habbash et al., 2016). The current ratio is used to account for firms' liquidity to test the ability of funds to meet their short-term obligations (Watson et al., 2002; 
Barako et al., 2006; Lan et al., 2013). Firms' growth rate is determined by the change in sales from one year to another (Hassanein and Hussainey, 2015). In addition, the company's age is expressed as the natural logarithm of the number of years' since their establishment (Hossain, 2008; Sehar $e t$ al., 2013; Habbash et al., 2016).

\section{Voluntary disclosure control variables (second proxy "Disclosure tone")}

For our model, when we use disclosure tone as a dependent variable to test $\mathrm{H} 2$, we use a number of control variables. Firm size is measured by the natural logarithm of total assets (Hackston and Milne, 1996; Kang and Gray, 2011; Hassan et al., 2006; Ressas and Hussainey, 2014; Aly et al., 2018). Financial leverage is proxied for by the total debt to total assets (Barako et al., 2006; Ressas and Hussainey, 2014; Aly et al., 2018). Firm profitability, a firm's ROA ratio is used (Kun Wang et al., 2008; Ressas and Hussainey, 2014). LOSS is a dummy variable for reporting a net loss (Rogers et al., 2011). Firms' growth rate is calculated as the change in sales from one year to another (Ressas and Hussainey, 2014; Hassanein and Hussainey, 2015; Aly et al., 2018). Marketto-book ratio is employed to control for a company's investment opportunity and growth potential (Martikainen et al., 2016; Czerney et al., 2017). DIV is a dummy variable for dividend payments (Hussainey and Aal-Eisa, 2009; Ressas and Hussainey, 2014) and firm age is shown as the natural logarithm of the number of years' since their establishment (Muttakin and Khan, 2014; Aly et al., 2018).

\subsection{Research model}

The relationship between the dependent variable voluntary disclosure (first proxy "VOLDIS" and second proxy "DISTONE"), the independent variable corporate investment efficiency and the control variables can be expressed in the following regression models. Models 1 and 2 show the relationship between voluntary disclosure first proxy "VOLDIS" and both of investment efficiency 
measurements. Models 3 and 4 present the association between voluntary disclosure second proxy

"DISTONE" and investment efficiency measurements.

$\operatorname{VOLDIS}_{i, t}=\beta 0+\beta 1 I N V E F F(1)_{i, t}+\beta 2 F S_{i, t}+\beta 3 L E V_{i, t}+\beta 4 P R O F_{i, t}+\beta 5 L I Q_{i, t}+\beta 6 S G_{i, t}+\beta 7 A G E_{i, t}$ $+\sum$ Industry dummies $+\sum$ Year dummies $+\varepsilon_{i, t}($ Model 1)

$\operatorname{VOLDIS}_{i, t}=\beta 0+\beta 1 I N V E F F(2)_{i, t}+\beta 2 F S_{i, t}+\beta 3 L E V_{i, t}+\beta 4 P R O F_{i, t}+\beta 5 L I Q_{i, t}+\beta 6 S G_{i, t}+\beta 7 A G E_{i, t}$ $+\sum$ Industry dummies $+\sum$ Year dummies $+\varepsilon_{i, t}($ Model 2)

Where;

- VOLDIS= Voluntary disclosure

- $\operatorname{INVEFF}(1)=$ Corporate investment efficiency (measurement 1)

- $\operatorname{INVEFF}(2)=$ Corporate investment efficiency (measurement 2)

- $\mathrm{FS}=$ Firm size

- $\mathrm{LEV}=$ Financial leverage

- $\mathrm{PROF}=$ Firm profitability

- $\quad$ LIQ= Firm liquidity

- $\mathrm{SG}=$ Firm's sales growth

- $\mathrm{AGE}=$ Firm age

- $\varepsilon=$ Error term

$\operatorname{DISTONE}_{i, t}=\beta 0+\beta 1 \operatorname{INVEFF}(1)_{i, t}+\beta 2 F S_{i, t}+\beta 3 L E V_{i, t}+\beta 4 P R O F_{i, t}+\beta 5$ OOSS $_{i, t}+\beta 6 S G_{i, t}+$ $\beta 7 M T B_{i, t}+\beta 8 D I V_{i, t}+\beta 9 A G E_{i, t}+\sum$ Industry dummies $+\sum$ Year dummies $+\varepsilon_{i, t}($ Model 3)

DISTONE $_{i, t}=\beta 0+\beta 1 I N V E F F(2)_{i, t}+\beta 2 F S_{i, t}+\beta 3 L E V_{i, t}+\beta 4 P R O F_{i, t}+\beta 5 L_{O S S}+\beta S_{i, t}+\beta 6 G_{i, t}+$ $\beta 7 \mathrm{MTB}_{i, t}+\beta 8 D I V_{i, t}+\beta 9 A G E_{i, t}+\sum$ Industry dummies $+\sum$ Year dummies $+\varepsilon_{i, t}$ (Model 4)

Where;

- DISTONE= Disclosure tone

- $\operatorname{INVEFF}(1)=$ Corporate investment efficiency (measurement 1$)$

- $\operatorname{INVEFF}(2)=$ Corporate investment efficiency (measurement 2)

- $\mathrm{FS}=$ Firm size

- $\mathrm{LEV}=$ Financial leverage

- $\quad \mathrm{PROF}=$ Firm profitability

- $\mathrm{LOSS}=\mathrm{A}$ binary variable (1 if a firm reported negative net income and 0 otherwise)

- $\mathrm{SG}=$ Firm's sales growth

- $\mathrm{MTB}=$ Market-to-book ratio

- $\mathrm{DIV}=\mathrm{A}$ binary variable (1 if a firm paid out dividends and 0 otherwise)

- $\mathrm{AGE}=$ Firm age

- $\varepsilon=$ Error term 


\section{Empirical Findings}

\section{Descriptive statistics and Pearson correlation}

Table (2) shows that the average of the investment efficiency in both models is around zero (0.0002 and -0.0005 respectively) which is a good indication of the samplefirms. As values become closer to zero, investment efficiency becomes higher (Gomariz and Ballesta, 2014). As for the dependent variables, VOLDIS and DISTONE, voluntary disclosure (VOLDIS) have a mean of 3.96, which indicates that 9104 words of the keywords are about performance actually disclosed by the firms of the sample. Disclosure tone (DISTONE) has a mean of 0.328 , which indicates that only $0.33 \%$ of the performance keywords actually reflect good news and are disclosed by the sample firms. The mean firm size for UK firms is $1,799,360,000$ (3.20) billion British Pound as the value of firm assets. Financial leverage (LEV) has a mean of $20.3 \%$ indicating that the sample firms are not highly leveraged (Habbash et al., 2016). Firm profitability (PROF) reflects an average of 0.064; Firm liquidity (LIQ) has a mean of 1.43; Firm sales growth (SG) has a mean of 7.24 similar to Hassanein and Hussainey (2015) findings. Capital expenditure to total assets (CAPTA) has an average of 0.039 . The average firm has been in existence for 65 years (as 1.802 is after applying the natural logarithm). The analysis also shows that firm loss (LOSS) has a mean of 0.077; Marketto-book ratio (MTB) has an average of 1.664 and dividends distribution (DIV) has a mean of 0.936. As for correlation results, tables (3) and (4) show that both models of investment efficiency (err and err2) have an insignificant positive relationship with voluntary disclosure and an insignificant negative one with disclosure tone. Considering the control variables, FS and LEV show a positive significant relationship with VOLDIS, with a $99 \%$ and $95 \%$ confidence levels respectively. The remaining variables have an insignificant relation with VOLDIS, with respect to liquidity having a negative association. PROF, SG, and MTB show a positive significant relationship with DISTONE, having a 99\% confidence levels. Also, LOSS has a significant but negative relationship 
with DISTONE with a confidence level of $99 \%$. The remaining control variables FS, DIV, LEV, and AGE have an insignificant relationship, as FS and LEV have a negative relation while DIV and AGE has a positive relation.

INSERT TABLES (2), (3) and (4) HERE

\section{Regression analysis}

Table (5) shows that the independent variable (err2) in the second model for measuring INVEFF has a positive significant relationship with VOLDIS. The first model's variable (err) still has a negative insignificant relation with VOLDIS. The second model's results are supported by signaling theory, as Foster (1986) and Inchausti (1997) state that profitable well-performing firm managers are encouraged to disclose more. Disclosure is considered one of the signaling means to attract investments, improve firms' reputation and justify managers' compensation (Ross, 1977; Verrecchia, 1983; Campbell et al., 2002). Investing efficiently is a sign of good performance and so disclosing such information would achieve the stated benefits. Therefore, accepting and supporting $H 1$.

As for the control variables for both models, FS shows a positive significant relation with VOLDIS with a 99\% confidence level, while PROF has a positive significant relation with confidence level 90\% for model 1 only. The remaining control variables reveal an insignificant association with VOLDIS with respect to LEV and AGE having a positive relationship and LIQ and SG having a positive one.

\section{INSERT TABLE (5)}

\section{Considering DISTONE as the dependent variable}

Table (6) presents the results of testing the relationship between investment efficiency and disclosure tone. It shows that INVEFF for model 1 (err "Chen et al. (2011)") has a significant relationship with DISTONE while model 2 (err2 "Biddle et al. (2009)") has an insignificant one. 
The results obtained support Chen et al. (2017) findings for over-investment as they find a negative association between INVEFF and transparency. Therefore, $H 2$ will be accepted. When firms are having investment inefficiencies through over or under-investing, they would try to cover these inefficiencies through disclosing more good news. Managers would never give a negative impression about the firm by disclosing the true investment decisions or activities (Aerts, 2005; Merkl-Davies et al., 2011; Leung et al., 2015). On the opposite, if managers were undertaking efficient investment opportunities, they would not be eager to disclose such kind of information. As according to the proprietary costs theory, firms must be aware of the costs of information dissemination if disclosing too much information, which could result in the damage of their competitive advantage (Verrecchia, 1983; McKinnon, 1984).

Considering the control variables, SG and MTB show a positive significant relation with DISTONE with confidence levels of $99 \%$ for SG while $90 \%$ and $95 \%$ for MTB in the two models respectively. LOSS and AGE have a negative significant association with DISTONE with 90\% and $95 \%$ as well. On the contrary, FS, LEV, PROF and DIV have an insignificant relationship with DISTONE.

INSERT TABLE (6)

\subsection{Additional analysis: The bidirectional relationship between disclosure and investment efficiency}

According to Velte (2019) the bidirectional relationship between investment efficiency and disclosure would be of major importance to discuss. The other way round relationship between corporate investment efficiency and voluntary disclosure was tested by previous studies discussed earlier in the literature review section (Cheng et al., 2013; Lai et al., 2014). Considering the effect of voluntary disclosure on corporate investment efficiency is a main concern, so testing that relationship using the appropriate control variables used by prior research was important. Table 
(7) gives an overview of the additional analysis results testing this relationship using the Heckman Model. This model is considered a more robust methodology to address that direction of association. To address the possible reversed causality, the Heckman test was conducted on the investment efficiency-disclosure link using the following models:

err $_{i, t}=\beta 0+\beta 1$ Logwordcount $_{i, t}+\beta 2$ SIZE $_{i, t}+\beta 3 L E V_{i, t}+\beta 4 R_{1, t}+\beta 5$ CurrentRatio $_{i, t}+\beta 6 A G E_{i, t}+$ $\beta 7$ MtoB $_{i, t}+\beta 8$ CFOS $_{i, t}+\beta 9 S T D C F O_{i, t}+\beta 10 S T D S_{i, t}+\beta 11$ TANG $_{i, t}+\beta 12$ ZSCORE $_{i, t}+\beta 13 D I V_{i, t}+$ $\beta 14 L O S S_{i, t}+\sum$ Industry dummies $+\sum$ Year dummies $+\varepsilon_{i, t}$ (Model 1)

$\operatorname{err}_{i, t}=\beta 0+\beta 1$ Logwordcount $_{i, t}+\beta 2$ SIZE $_{i, t}+\beta 3 L E V_{i, t}+\beta 4 R O A_{i, t}+\beta 5$ CurrentRatio $_{i, t}+\beta 6 A G E_{i, t}+$ $\beta 7$ MtoB $_{i, t}+\beta 8$ CFOS $_{i, t}+\beta 9 S T D C F O_{i, t}+\beta 10 S T D S_{i, t}+\beta 11$ TANG $_{i, t}+\beta 12$ ZSCORE $_{i, t}+\beta 13 D I V_{i, t}+$ $\beta 14$ LOSS $_{i, t}+\sum$ Industry dummies $+\sum$ Year dummies $+\varepsilon_{i, t}($ Model 2)

$\operatorname{err}_{i, t}=\beta 0+\beta 1$ TONE $_{i, t}+\beta 2$ SIZE $_{i, t}+\beta 3 L E V_{i, t}+\beta 4 R O A_{i, t}+\beta 5$ CurrentRatio $_{i, t}+\beta 6 A G E_{i, t}+\beta 7 M t o B_{i, t}+$ $\beta 8$ CFOS $_{i, t}+\beta 9 S T D C F O_{i, t}+\beta 10 S T D S_{i, t}+\beta 11 T A N G_{i, t}+\beta 12$ ZSCORE $_{i, t}+\beta 13 D I V_{i, t}+\beta 14$ LOSS $_{i, t}+$ $\sum$ Industry dummies $+\sum$ Year dummies $+\varepsilon_{i, t}($ Model 3)

err $2_{i, t}=\beta 0+\beta 1$ TONE $_{i, t}+\beta 2$ SIZE $_{i, t}+\beta 3 L E V_{i, t}+\beta 4 R_{\text {OOA }} A_{i, t}+\beta 5$ CurrentRatio $_{i, t}+\beta 6 A G E_{i, t}+\beta 7 M t o B_{i, t}+$ $\beta 8$ CFOS $_{i, t}+\beta 9 S T D C F O_{i, t}+\beta 10 S T D S_{i, t}+\beta 11 T A N G_{i, t}+\beta 12 Z_{S C O R E_{i, t}}+\beta 13 D I V_{i, t}+\beta 14 L O S S_{i, t}+$ $\sum$ Industry dummies $+\sum$ Year dummies $+\varepsilon_{i, 1}($ Model 4)

The results of the first and second models show that voluntary disclosure has a positive significant effect on corporate investment efficiency with a confidence level of $99 \%$ in the response model. After the truncation done by the selection model, the significance reaches $90 \%$, which indicates that even if after correcting the biasness of data still the association remains between both variables. These results are consistent with Zhong and Gao (2017), which show that CSR disclosure contributes to higher FRQ and thereof reduced information asymmetry and improved investment efficiency. In addition, Dutta and Nezlobin (2017) support these findings by concluding that cash flows and capital stock disclosures contribute to the efficiency of investment decisions. The results of the third and fourth models testing the disclosure tone impact on investment efficiency show insignificant relationships between the variables. Therefore, it can be concluded that there is a bidirectional relationship between disclosure practices and corporate investment efficiency, indicating that neither of these variables represent a starting point for firms 
to take care of. Both firms' investment efficiency and disclosure practices lead to each other, which encourage managers to assign the same level of attention and importance to them.

\section{Summary}

We aimed to test the effect of corporate investment efficiency on voluntary disclosure. The sample was selected from FTSE all share index for the period from 2007 until 2014. We find that investment efficiency affects voluntary disclosure (first measurement) positively for the second model only (Biddle et al., 2009). Consistent with the signaling theory, an increased level of transparency when firms invest efficiently would act as a positive signal to stakeholders, and thereof improves managers' image, firms' reputation and the ability to raise equity when needing. Vice versa in a situation of over or under investment, the non-disclosure of such information would protect managers from being replaced or a decline that might happen on the share price. On the other side, the inefficiency of investments would not be of good news to be shared with a firm's stakeholders. Firms will not prefer to disclose such information, which would have an adverse effect on all parties. These results are not consistent with that of Chen et al. (2017) which found a negative effect of investment transparency on voluntary disclosure. As for the disclosure tone (second measurement of voluntary disclosure), the first model (Chen et al., 2011) shows a negative effect of investment efficiency on it. This negative association was explained by the proprietary costs theory as when a firm's investment efficiency rise, managers become aware that disclosing more information would harm their firms' competitive advantage.

Therefore, it can be concluded that the findings of this paper would be of great importance to stakeholders and corporations. Stakeholders' investment decisions could be facilitated by understanding the disclosures provided by their firms and how these firms' performance is presented. Also, due to the bidirectional relationship between investment efficiency and disclosure, stakeholders must be aware that as their decisions are affected by firms' disclosure practices still 
they do affect these decisions on the hand. For example, as an investor might think that it is a good opportunity to invest in a firm with promising disclosures, he or she should consider that this investment might contribute in generating more income or profits from projects, which are disclosed about by the management.

The study's limitations lie in the sample timing and voluntary disclosure measurement. The sample timing is from 2007 until 2014, it was better to extend it to more recent years to have a clearer picture for firms' performance. The voluntary disclosure measurement considered only the performance commentary scores not the overall disclosure score. A justification was provided for both limitations; data availability was the reason for limiting the sample timing by 2014 as these are the only provided data by the CFIE. In addition, choosing the performance commentary was due to the need of being precise and explores the commentary, which most reflects a company's investment efficiency performance instead of analysing an aggregate one.

There is more than one opportunity for extending this research in the future; a comparative study including more than one country would be beneficial, as well as employing other investment efficiency and managerial ability proxies to study their effect on voluntary disclosure.

\section{References}

Abernathy, J., Kubick, T. and Masli, A. (2018). Evidence on the relation between managerial ability and financial reporting timeliness. International Journal of Auditing, 22(2), 185-196.

Aerts, W. (2005). Picking up the pieces: impression management in the retrospective attributional framing of accounting outcomes. Accounting, Organizations and Society, 30(6), 493-517.

Aerts, W. and Tarca, A. (2010). Financial performance explanations and institutional setting. Accounting and Business Research, 40(5), 421-450.

Al-Hadi, A., Hasan, M. and Habib, A. (2016). Risk committee, firm life cycle, and market risk disclosures. Corporate Governance: An International Review, 24(2), 145-170.

Aly, D. and Hussainey, K. and Elhalaby, S. (2018). Tone disclosure and financial performance: Evidence from Egypt. Accounting Research Journal, 31(1), 63-74. 
Athanasakou, V. and Hussainey, K. (2014). The perceived credibility of forward-looking performance disclosures The perceived credibility of forward-looking performance disclosures. Accounting and Business Research, 44 (3), 227-259.

Baik, B., Farber, D. and Lee, S. (2011). CEO ability and management earnings forecasts. Contemporary Accounting Research, 28(5), 1645-1668.

Baik, B., Brockman, P., Farber, D. and Lee, S. (2017). Managerial ability and the quality of firms' information environment. Journal of Accounting, Auditing and Finance, 1-22.

Bamber, L., Jiang, J. and Wang, I. (2010). What's my style? The influence of top managers on voluntary corporate financial disclosure. The Accounting Review, 85(4), 1131-1162.

Barako, D., Hancock, P. and Izan, H. (2006). Factors influencing voluntary corporate disclosure by Kenyan companies. Corporate Governance: An International Review, 14(2), 107-125.

Biddle, G., Hilary, G. and Verdi, R. (2009). Financial reporting quality and investment efficiency. Journal of Accounting and Economics, 48(2-3), 112-131.

Campbell, D., Shrives, P. and Bohmbach-Saager, H. (2002). Voluntary disclosure of mission statements in corporate annual reports: Signaling what and to whom? Business and society review, $106(1), 65-87$.

Chapman, K. and Green, J. R. (2018). Analysts' influence on managers' guidance. The Accounting Review, 93(1), 45-69.

Chen, F., Hope, O., Li, Q. and Wang, X. (2011). Financial reporting quality and investment efficiency of private firms in emerging markets. The Accounting Review, 86(4), 1255-1288.

Chen, L., Dong, Y., Ng, J. and Tsang, A. (2017). Cross-listings and Voluntary Disclosure: International Evidence. Retrieved from http://www.efmaefm.org/0EFMAMEETINGS/EFMA\%20ANNUAL\%20MEETINGS/2017Athens/papers/EFMA2017_0286_fullpaper.pdf

Chen, JG, Smith, D. and Wirth, C. (2017). How is investment efficiency related to investment transparency? Retrieved from https://ssrn.com/abstract $=3005686$

Cheng, M., Dhaliwal, D. and Zhang, Y. (2013). Does investment efficiency improve after the disclosure of material weaknesses in internal control over financial reporting?'. Journal of Accounting and Economics, 56(1), 1-18.

Clatworthy, M. and Jones, M. (2006). Differential patterns of textual characteristics and company performance in the chairman's statement. Accounting, Auditing and Accountability Journal, 19(4), 493-511.

Cooke, T. (1989). Voluntary corporate disclosure by Swedish companies. Journal of Accounting and Business Research, 19 (74), 113-124.

Cooke, T. (1998). Regression analysis in accounting disclosure studies. Accounting and business research, 28(3), 209-224. 
Courtis, J. (2004). Corporate report obfuscation: artefact or phenomenon? British Accounting Review, 36(3), 291-312.

Czerney, K., Lisic, L., Wu, B. and Zhang, I. (2017). Big 4 Auditors, Litigation Risk, and Disclosure Tone. Retrieved from CUHK business school, https://www.bschool.cuhk.edu.hk/events/big-4auditors-litigation-risk-and-disclosure-tone/

Demerjian, P., Lev, B. and McVay, S. (2012). Quantifying managerial ability: A new measure and validity tests. Management Science, 58(7), 1229-1248.

Demerjian, P., Lev, B., Lewis, M. and McVay, S. (2013). Managerial Ability and Earnings Quality. The Accounting Review, 88(2), 463-498.

Dutta, S. and Nezlobin, A. (2017). Dynamic effects of information disclosure on investment efficiency. Journal of Accounting Research, 55(2), 329-369.

El Haj, M., Alves, P., Rayson, P., Walker, M. and Young, S. (2019). Retrieving, classifying and analysing narrative commentary in unstructured (Glossy) annual reports published as PDF files. Journal of accouting and business research, 1-29.

El Haj, M., Rayson, P., Walker, M. and Young, S. And Simaki, V. (2019). In search of meaning: Lessons, resources and next steps for computational analysis of financial disclosure. Journal of business finance and accounting,46(3-4), 265-306.

Eng, L. and Mak, Y. (2003). Corporate governance and voluntary disclosure. Journal of Accounting and Public Policy, 22(4), 325-345.

Foster. G. (1986). Financial Statement Analysis. Retrieved from https://www.abebooks.com/Financial- Statement-Analysis-2nd-Edition-George/9006759114/bd.

Godfrey, J., Mather, P. and Ramsay, A. (2003). Earnings and impression management in financial reports: the case of CEO changes. ABACUS, 39(1), 95-123.

Gomariz, M. and Ballesta, J. (2014). Financial reporting quality, debt maturity and investment efficiency. Journal of Banking and Finance, 40, 494-506.

Gul, F., Khedmati, M., Lim, E. and Navissi, F. (2018). Managerial ability, financial distress, and audit fees. Accounting Horizons, 32(1), 29-51.

Guttman, I. and Meng, X. (2018).The Effect of Voluntary Disclosure on Investment Inefficiency. Retrieved from New York University, https://ssrn.com/abstract=3303486.

Habbash, M., Hussainey, K. and Awad, E. (2016). The determinants of voluntary disclosure in Saudi Arabia: an empirical study. International Journal of Accounting, Auditing and Performance Evaluation, 12(3), 213-236.

Habib, A. and Hasan, M. (2018). Managerial ability, investment efficiency and stock price crash risk. Research in International Business and Finance, 42 262-274. 
Hackston, D. and Milne, M. (1996). Some determinants of social and environmental disclosures in New Zealand companies. Accounting, Auditing and Accountability Journal, 9(1), 77-108.

Hassan, O. Giorgioni, G. and Romilly, P. (2006). The extent of accounting disclosure and its determinants in an emerging capital market: the case of Egypt. International Journal of Accounting, Auditing and Performance Evaluation, 3(1), 41-67.

Hassanein, A. and Hussainey, K. (2015). Is forward-looking financial disclosure really informative? Evidence from UK narrative statements. International Review of Financial Analysis, 41, 5261.

Hossain, M. (2008). The extent of disclosure in annual reports of banking companies: the case of India, European Journal of Scientific Research, 23(4), 660-681.

Hubbard, R. (1998). Capital-market imperfections and investment. Journal of Economic Literature, 36(1), 193-225.

Hussainey, K. and Aal-Eisa (2009). Disclosure and dividend signalling when sustained earnings growth declines. Managerial Auditing Journal, 24(5), 445-454.

Inchausti, B. (1997). The influence of company characteristics and accounting regulation on information disclosed by Spanish firms. European Accounting Review, 6(1).

Kang, H. and Gray, S. (2011). Reporting intangible assets: voluntary disclosure practices of top emerging market companies. International Journal of Accounting, 46(4), 402-423.

Kun Wang, Sewon, O. and Claiborne, M. (2008). Determinants and consequences of voluntary disclosure in an emerging market: evidence from China. Journal of International Accounting, Auditing and Taxation, 17(1), 14-30.

Lai, S., Liu, C. and Wang, T. (2014). Increased disclosure and investment efficiency. Asia-Pacific Journal of Accounting and Economics, 21(3), 308-327.

Lan, Y., Wang, L. and Zhang, X. (2013). Determinants and features of voluntary disclosure in the Chinese stock market. China Journal of Accounting Research, 6(4), 265-285.

La Porta, R., Lopez-De-Silanes, F. and Shleifer, A. (2006). What works in securities laws? Journal of Finance, 61(1), 1-32.

Lee, C., Wang, C., Chiu, W. and Tien, T. (2018). Managerial ability and corporate investment opportunity. International Review of Financial Analysis, 57, 65-76.

Leung, S., Parker, L. and Courtis, J. (2015). Impression management through minimal narrative disclosure in annual reports. The British Accounting Review, 47(3), 275-289.

Lewis, C. and Young, S. (2019). Fad or future?; Automated analysis of financial text and its implications for corporate reporting. Journal of accounting and business research, 49(5), 587-615. 
Martikainen, M, Miihkinen, A. and Watson, L. (2016). Board Characteristics and Disclosure Tone. Retrieved from University of Florida, https://www1.warrington.ufl.edu/accounting/docs/2016_Paper3.pdf.

McKinnon, S. (1984). A cost-benefit study of disclosure requirements for multinational corporations. Journal of Business Finance and Accounting, 11(4), 451-468.

Merkl-Davies, D., Brennan, N. and McLeay, S. (2011). Impression management and retrospective sense-making in corporate narratives: a social psychology perspective. Accounting, Auditing and Accountability Journal, 24(3), 315-344.

Mohamed, A. and Schwienbacher, A. (2016). Voluntary disclosure of corporate venture capital investments. Journal of Banking and Finance, 68, 69-83.

Muttakin, M. and Khan, A. (2014). Determinants of corporate social disclosure: Empirical evidence from Bangladesh. Advances in Accounting, incorporating Advances in International Accounting, 30(1), 168-175.

Pappas, K. (2015). Three Essays on Earnings Management : Evidence from the UK. University of Manchester. Manchester.

Ressas, M. and Hussainey, K. (2014). Does financial crisis affect financial reporting of good news and bad news? International Journal of Accounting, Auditing and Performance Evaluation, 10(4), 410-429.

Richardson, S. (2006). Over-investment of free cash flow. Review of Accounting Studies, 11(2/3), 159-189. doi: 10.1007/s11142-006-9012-1.

Rogers, J., Buskirk, A. and Zechman, S. (2011). Disclosure tone and shareholder litigation. The Accounting Review, 86(6), 2155-2183.

Ross, S. (1977). The determination of financial structure: The incentive signaling approach. Bell Journal of Economics 8(1), 23-40.

Sehar, N., Bilal and Tufail, S. (2013). Determinants of voluntary disclosure in annual reports: a case study of Pakistan. Management and Administrative Sciences Review, 2(2), 181-195.

Trueman, B. (1986). Why do managers voluntarily release earnings forecasts? Journal of Accounting and Economics, 8(1), 53-72.

Velte, P. (2019). The bidirectional relationship between ESG performance and earnings management-empirical evidence from Germany. Journal of Global Responsibility, 10(4), 322-338.

Verrecchia, R. (1983). Discretionary disclosure. Journal of Accounting and Economics, 5, 179194. 
Watson, A., Shrives, P. and Marston, C. (2002). Voluntary Disclosure of Accounting Ratio in the UK. TheBritish Accounting Review, 34(4), 289-313.

Zhong, M. and Gao, L. (2017). Does corporate social responsibility disclosure improve firm investment efficiency? Evidence from China. Review of Accounting and Finance, 16(3), 348-365.

Table (1)

Sample Sector Classification

\begin{tabular}{|c|c|c|}
\hline Sector & $\begin{array}{c}\text { No. of companies in the } \\
\text { Sector }\end{array}$ & \% \\
\hline Materials & 14 & $9.27 \%$ \\
\hline Consumer staples & 12 & $7.95 \%$ \\
\hline Energy & 7 & $4.64 \%$ \\
\hline Consumer discretionary & 37 & $24.5 \%$ \\
\hline Utilities & 6 & $3.97 \%$ \\
\hline Industrials & 51 & $33.77 \%$ \\
\hline Telecommunications & 4 & $2.66 \%$ \\
\hline Healthcare & 6 & $3.97 \%$ \\
\hline IT & 14 & $9.27 \%$ \\
\hline Total & $\mathbf{1 5 1}$ & $\mathbf{1 0 0 \%}$ \\
\hline
\end{tabular}

Table (2)

Descriptive Statistics for 2007-2014

\begin{tabular}{lccccc}
\hline Variables & Mean & Max & Min & Std. Dev. & Skewness \\
\hline VOLDIS & 3.96 & 4.76 & 1.83 & 0.332 & -1.850 \\
DISTONE & 0.33 & 0.69 & -0.12 & 0.15 & -0.309 \\
INVEFF1 (err) & 0.0002 & 24.75 & -9.51 & 4.26 & 2.384 \\
INVEFF2 (err2) & -0.0005 & 73.22 & -54.24 & 10.89 & 2.37 \\
$\boldsymbol{F S}$ & 3.20 & 5.09 & 1.84 & 0.63 & 0.464 \\
LEV & 0.203 & 0.69 & 0.00 & 0.14 & 0.653 \\
$\boldsymbol{P R O F}$ & 0.064 & 0.70 & -0.48 & 0.079 & 1.482 \\
LIQ & 1.43 & 6.10 & 0.35 & 0.75 & 1.914 \\
SG & 7.24 & 152.79 & -45.16 & 16.23 & 2.063 \\
$\boldsymbol{C A P T A}$ & 0.039 & 0.28 & 0.00 & 0.040 & 2.432 \\
$\boldsymbol{A G E}$ & 1.802 & 2.47 & 0.00 & 0.389 & -0.977 \\
LOSS & 0.077 & 1.00 & 0.00 & 0.267 & 3.184 \\
$\boldsymbol{M T B}$ & 1.66 & 5.47 & 0.55 & 0.738 & 1.695 \\
DIV & 0.936 & 1.00 & 0.00 & 0.24 & -3.580 \\
\hline
\end{tabular}

VOLDIS is voluntary disclosure measured as the word count for the aggregate performance commentary identified as wordcountsum_Perform; DISTONE is disclosure tone measured as the net positive keywords divided by positive plus negative keywords for the performance commentary selected known as net_tone_performance; INVEFF is investment efficiency measured by the negative and positive residuals of the investment equation; FS is firm size measured as the natural logarithm of total assets; LEV is firm leverage measured as total liabilities divided by total assets; PROF is firm profitability measured by the return on assets ratio of a firm; LIQ is firm liquidity measured by the firm's current ratio by dividing current assets by current liabilities; SG is sales growth measured by the change which is sales from year to year; CAPTA is capital expenditure divided by total assets; AGE is firm age measured as the natural logarithm of the number of years' since their establishment; LOSS is a dummy variable for reporting a net loss; MTB is market-to-book ratio; DIV is a dummy variable for dividend payments. 
Table (3)

Pearson's Correlation Matrix for (2007-2014)

\begin{tabular}{|c|c|c|c|c|c|c|c|c|c|c|}
\hline Variables & $F S$ & $L E V$ & PROF & $L I Q$ & $S G$ & CAPTA & $A G E$ & $E r r$ & $e r r 2$ & VOLDIS \\
\hline$\overline{F S}$ & 1 & $.291^{\text {** }}$ & -.052 & $-.198^{* *}$ & -.028 & .024 & $.110^{*}$ & .050 & $-.116^{* * *}$ & $.391^{* *}$ \\
\hline$L E V$ & & 1 & $-.140^{* *}$ & $-.249^{* *}$ & -.008 & $.256^{* *}$ & .073 & $.209^{* *}$ & .030 & $.094^{*}$ \\
\hline PROF & & & 1 & .036 & $.129^{* *}$ & .072 & $.126^{* *}$ & 0.068 & $.131^{\text {** }}$ & .006 \\
\hline$L I Q$ & & & & 1 & .006 & $-.108^{*}$ & $.087^{*}$ & -.081 & -.054 & -.057 \\
\hline$S G$ & & & & & 1 & $.100^{*}$ & .017 & .000 & .000 & .019 \\
\hline CAPTA & & & & & & 1 & .079 & $.943^{* *}$ & $.303^{* *}$ & .020 \\
\hline$A G E$ & & & & & & & 1 & .046 & -.050 & .026 \\
\hline Err & & & & & & & & 1 & $.388^{* *}$ & .055 \\
\hline err2 & & & & & & & & & 1 & .030 \\
\hline VOLDIS & & & & & & & & & & 1 \\
\hline
\end{tabular}

** Correlation is significant at the 0.01 level (2-tailed).

* Correlation is significant at the 0.05 level (2-tailed).

Variable definitions: see table (2)

Table (4)

Pearson's Correlation Matrix for (2007-2014)

\begin{tabular}{|c|c|c|c|c|c|c|c|c|c|c|c|}
\hline Variables & $F S$ & $L E V$ & PROF & LOSS & $S G$ & $M T B$ & DIV & $A G E$ & Err & err2 & DISONE \\
\hline$F S$ & 1 & $.291^{* * *}$ & -.052 & -.019 & -.028 & $-.181^{* *}$ & $-.118^{* * *}$ & $.110^{*}$ & .050 & $-.116^{* *}$ & -.046 \\
\hline$L E V$ & & 1 & $-.140^{* *}$ & .043 & -.008 & $-.182^{* *}$ & .011 & .063 & $.209^{* *}$ & .030 & -.085 \\
\hline PROF & & & 1 & $-.455^{* *}$ & $.129^{* *}$ & $.451^{* *}$ & $.122^{* *}$ & .070 & .068 & $.131^{* *}$ & $.167^{* *}$ \\
\hline LOSS & & & & 1 & $-.109^{*}$ & $-.178^{* *}$ & $-.126^{* *}$ & -.083 & -.053 & .018 & $-.192^{* *}$ \\
\hline$S G$ & & & & & 1 & $.101^{*}$ & $.090^{*}$ & .066 & .000 & .000 & $.151^{* *}$ \\
\hline MTB & & & & & & 1 & $.125^{* *}$ & -.034 & .046 & $.170^{* *}$ & $.217^{* *}$ \\
\hline$D I V$ & & & & & & & 1 & .057 & .017 & -.033 & .050 \\
\hline$A G E$ & & & & & & & & 1 & .041 & $-.098^{*}$ & .002 \\
\hline Err & & & & & & & & & 1 & $.388^{* *}$ & -.080 \\
\hline err2 & & & & & & & & & & 1 & -.060 \\
\hline DISTONE & & & & & & & & & & & 1 \\
\hline
\end{tabular}

** Correlation is significant at the 0.01 level (2-tailed).

* Correlation is significant at the 0.05 level (2-tailed).

Variable definitions: see table (2)

Table (5)

Corporate investment efficiency and voluntary disclosure

\begin{tabular}{|c|c|c|c|c|c|}
\hline & \multicolumn{2}{|c|}{ Model 1} & \multicolumn{2}{|c|}{ Model 2} & \multirow[t]{2}{*}{ Predicted sign } \\
\hline Variables & Coefficients & Significance & Coefficients & Significance & \\
\hline Constant & 3.382 & 0.000 & 3.314 & 0.000 & NA \\
\hline Err & -0.013 & 0.772 & 0.126 & 0.003 & + \\
\hline$F S$ & 0.499 & 0.000 & 0.518 & 0.000 & + \\
\hline$L E V$ & 0.017 & 0.721 & 0.011 & 0.820 & + \\
\hline PROF & 0.079 & 0.079 & 0.060 & 0.180 & + \\
\hline$L I Q$ & -0.014 & 0.754 & -0.003 & 0.946 & $+/-$ \\
\hline$S G$ & -0.044 & 0.326 & -0.028 & 0.533 & + \\
\hline$A G E$ & 0.042 & 0.359 & 0.046 & 0.307 & + \\
\hline $\begin{array}{l}\text { No. of } \\
\text { observations }\end{array}$ & \multicolumn{2}{|c|}{$\begin{array}{c}441 \\
34.3 \%\end{array}$} & \multicolumn{2}{|c|}{$\begin{array}{c}441 \\
35.7 \% \\
\end{array}$} & \\
\hline
\end{tabular}




\begin{tabular}{lcc}
\cline { 2 - 3 } $\boldsymbol{R}^{2}$ & $30.6 \%$ & $32.1 \%$ \\
Adjusted $\boldsymbol{R}^{2}$ & 9.429 & 10.032 \\
$\boldsymbol{F}$ value & 0.000 & 0.000 \\
ANOVA & Yes & Yes \\
Year dummy & Yes & Yes \\
Industry dummy & & \\
\hline
\end{tabular}

Variable definitions: see table (2)

Table (6)

Corporate investment efficiency and disclosure tone

\begin{tabular}{|c|c|c|c|c|c|}
\hline \multirow[b]{2}{*}{ Variables } & \multicolumn{2}{|c|}{ Model 1} & \multicolumn{2}{|c|}{ Model 2} & \multirow{2}{*}{$\begin{array}{c}\text { Predicted } \\
\text { sign }\end{array}$} \\
\hline & Coefficients & Significance & Coefficients & Significance & \\
\hline Constant & 0.293 & 0.000 & 0.290 & 0.000 & NA \\
\hline Err & -0.090 & 0.060 & -0.070 & 0.128 & + \\
\hline$F S$ & -0.044 & 0.395 & -0.035 & 0.499 & + \\
\hline$L E V$ & 0.060 & 0.237 & 0.049 & 0.323 & + \\
\hline PROF & 0.075 & 0.306 & 0.066 & 0.365 & + \\
\hline LOSS & -0.099 & 0.054 & -0.098 & 0.059 & $+/-$ \\
\hline$S G$ & 0.136 & 0.004 & 0.133 & 0.005 & + \\
\hline MTB & 0.123 & 0.054 & 0.135 & 0.037 & + \\
\hline$D I V$ & 0.034 & 0.451 & 0.034 & 0.461 & $+/-$ \\
\hline$A G E$ & -0.097 & 0.036 & -0.102 & 0.029 & + \\
\hline No. of observations & \multicolumn{2}{|c|}{428} & \multicolumn{2}{|c|}{428} & \\
\hline$R^{2}$ & \multicolumn{2}{|c|}{$28.6 \%$} & \multicolumn{2}{|c|}{$28.3 \%$} & \\
\hline Adjusted $R^{2}$ & \multicolumn{2}{|c|}{$24.3 \%$} & \multicolumn{2}{|c|}{$24.1 \%$} & \\
\hline F value & \multicolumn{2}{|c|}{6.727} & \multicolumn{2}{|c|}{6.656} & \\
\hline ANOVA & \multicolumn{2}{|c|}{0.000} & \multicolumn{2}{|c|}{0.000} & \\
\hline Year dummy & \multicolumn{2}{|c|}{ Yes } & \multicolumn{2}{|c|}{ Yes } & \\
\hline Industry dummy & \multicolumn{2}{|c|}{ Yes } & \multicolumn{2}{|c|}{ Yes } & \\
\hline
\end{tabular}

Table (7)

The bidirectional relationship between disclosure and investment efficiency

\begin{tabular}{lrrrr}
\multicolumn{4}{c}{ Response Equation - Investment efficiency "err" } \\
\hline \multicolumn{4}{c}{ Model 1 } & \multicolumn{2}{c}{ Model 2 } \\
\hline Variables & Coefficients & Significance & Coefficients & Significance \\
Constant & -8.631707 & 0.0000 & -6.772157 & 0.2796 \\
LOGWORDCOUNT & 0.311664 & 0.4683 & 4.072423 & 0.0067 \\
AGE & 20.42815 & 0.0000 & 0.581889 & 0.6481 \\
CFOS & -1.357017 & 0.0000 & 19.41867 & 0.0017 \\
CURRENTRATIO & 0.035039 & 0.7004 & -1.683050 & 0.0168 \\
INDUSTRY & 5.613086 & 0.0000 & -0.237745 & 0.3857 \\
LEV & 0.475247 & 0.3394 & 3.976896 & 0.2930 \\
LOSS & 0.594069 & 0.3694 & 4.270122 & 0.0261 \\
\hline
\end{tabular}




\begin{tabular}{lrccc}
\hline MTOB & -1.254236 & 0.0001 & 1.912080 & 0.0435 \\
ROA & -0.256542 & 0.9144 & 11.56824 & 0.1120 \\
SIZE & -0.550016 & 0.0690 & -3.745174 & 0.0000 \\
STDCFO & 18.87275 & 0.0006 & 24.53991 & 0.1395 \\
STDS & -0.291113 & 0.8006 & 7.218345 & 0.0393 \\
TANG & 8.072809 & 0.0000 & -4.063407 & 0.0941 \\
ZSCORE & 0.692536 & 0.0001 & -0.857287 & 0.1003 \\
\hline
\end{tabular}

Selection Equation - Investment efficiency "err"

\begin{tabular}{lrcrc}
\hline & \multicolumn{2}{c}{ Model 1 } & \multicolumn{2}{c}{ Model 2 } \\
\hline Variables & Coefficients & Significance & Coefficients & Significance \\
Constant & 2.011520 & 0.1475 & 1.315892 & 0.3559 \\
LOGWORDCOUNT & 0.463613 & 0.0731 & 0.471640 & 0.0906 \\
AGE & -0.826158 & 0.4605 & 0.223811 & 0.2410 \\
CFOS & -0.228141 & 0.0658 & 0.673564 & 0.4722 \\
CURRENTRATIO & -0.036212 & 0.5375 & -0.018772 & 0.8509 \\
INDUSTRY & 1.228385 & 0.1814 & 0.008634 & 0.8302 \\
LEV & 0.356008 & 0.2408 & 0.682930 & 0.3187 \\
LOSS & -0.258970 & 0.4958 & 0.179155 & 0.5432 \\
MTOB & 0.122888 & 0.5958 & 0.091564 & 0.6525 \\
ROA & 3.882709 & 0.0798 & 4.138898 & 0.0028 \\
SIZE & -0.484258 & 0.0106 & -0.528153 & 0.0006 \\
STDCFO & -1.250306 & 0.7423 & 1.431628 & 0.5979 \\
STDS & 0.577781 & 0.4782 & 0.659386 & 0.2826 \\
TANG & -1.480475 & 0.0121 & -1.454675 & 0.0007 \\
ZSCORE & 0.019928 & 0.8677 & -0.136134 & 0.2137 \\
\hline
\end{tabular}

